\title{
The Internet: An Avenue of Virtual Communication
}

\author{
Ahmet Ecirli \\ Dean. Lecturer, Hena e Plote Beder University, Tirana Albania \\ Ebrahim M. Daniel \\ Romanian Academy, Professor Ph.D., Scientific Secretary of the Department of Economics, \\ Law and Sociology of Romanian Academy, Bucharest, Romania, \\ E-Dangui \\ Romanian Academy, Associate researcher of National Economic Research Institute of the Romanian Academy, \\ Assistant Professor Ph. D, "Nicolae Titulescu" University, Bucharest, Romania,
}

\section{Doi:10.5901/ajis.2013.v2n8p660}

\section{Abstract}

The Internet is a "network of networks" that connects different ranks of several thousand information networks from dozens of countries around the world. It is a virtual network consisting of an ever-growing number of LAN (Local Area Network-LAN), public and private networks over large areas (Wide Area Network-WAN), regional and national networks that are interconnected (Vasiu, I., 1998). The digital revolution, based mostly on the internet hasn't gotten any halfway, "you haven't seen anything yet." (Ulieru, M. 2008). The Internet represents the biggest "neighborhood" of Cyberspace that makes available to users a few major categories: World Wide Web, Electronic Mail, Usenet, and Internet Relay Chat. The World Wide Web represents an "electronic marketplace" for goods, services and a wide range of applications. Different users constitute their sites, which are presented in Cyberspace as "showcases". The Internet is administered by the Internet Corporation for Assigned Names and Numbers (ICANN), which endorses the sites names and addresses; It depends directly on the US Department of Commerce and the US Government.

Keywords: Internet, virtual communication, cyberspace, e-marketplace, network of networks

\section{The Dimensions of Internet}

Nowadays, a very large number of databases are available, that thanks to the Internet can be accessed from any corner of the world, computer intelligence experiencing greater breadth and diversification. Companies, corporations and businesses in the most varied fields of activity are the most worried about information theft. Commercial information like product listings, pricing, customers, suppliers, methods of promoting products or marketing studies are the most "hunted" (Vasiu, I., 1998, p173). Furthermore manufacturing technologies, human resources training methods, know-how patentpending inventions etc. During 10-12 December 2003, in Geneva took place the first global meeting on the information society, organized at the request of ONU, from International Telecommunications Union (IUT). This major event of the communications market was compared, by the extent of its means and effects, with what represented for the environment, Earth Meeting in Rio de Janeiro in 1992.

The Internet has belonged to the greater public for less than 25 years. In a time so short it has upset the political, economic, social, cultural and associative life in whole countries. Nothing is as before in the world of communications. The signals acceleration delivery and the networks reliability have changed the ways to communicate, to study, to buy, to inform, to entertain, to organize, to learn and to work for an important part of our planets habitants. Internet has become a common name from a proper one.

George Săsărman classified very well encyclopedias in the Internet age: Zedler - was the first, composed by anonymous authors followed by the Wikipedia - a free internet dictionary, whose co-founder is Larry Sanger. He started from the idea that a collective wisdom product is better than that of a group of experts, no matter how qualified they are! Microsoft is preparing an encyclopedia - after the same typical, named Micropedia, while Lary Sanger has launched a new project- Citizendium, where authors are no longer anonymous, but among most proficient professionals, while 
readers have the opportunity to comment on texts and propose completeness. Knol (from knowledge) is the ultimate electronic encyclopedia. It is announced that Google will deal with its achievement.

Marc Ulieru offers, citing a study, TheCounter.com, the most known internet browsers ranking - interfaces operating the connection to the internet; They are as follows: Internet Explorer, the most popular, used by 73 percent of navigators from around the world even because it «comes preinstalled with the operating Widows system», Mozilla Firefox, used by 18 percent, Safari by 6 percent, and Opera - 3 percent.

More than 250 million Europeans use the Internet regularly. More than half of Europeans are now regular Internet users, 80 percent of them have broadband connections, while 60 percent of the public services offered at EU level are available online. Two-thirds of schools and half of doctors use fast connections to the internet, due to the strong development of broadband communications in Europe. "We are witnessing a welcome change of political orientation, given that all 27 EU Member States are promoting today the information and communication technology (ICT), the main factor of growth in Europe, in the framework of the respective States national policies. This helps Europe to compete internationally with other countries or developed world, modernizing the Europeans daily life, "said Viviane Reding, European Commissioner for information society and Media. In 2007, 77 percent of businesses in the EU, 67 percent of schools and 48 percent of physicians benefit of fast broadband connections. However, certain regions of the EU, being not fully connected, have yet to recover. Therefore, all EU countries must make more efforts in order to reduce differences, developing cross-border communication services as well as services covering rural and ultra-peripheral regions".

About 40 percent of Europeans do not use the Internet at all; percentages range from 69 percent (Romania), 65 percent (Bulgaria) and 62 percent (Greece), to 13 percent (Denmark, Netherlands). In order to encourage the use of new online technologies, the Commission will publish in 2008 a guide on the rights and obligations of EU users in the digital environment. Bulgaria has a penetration rate of 30 percent, Poland by 29.6 percent while in the EU it was 55.7 percent (of the 490 million EU population, 273 million are web surfers; therefore have access to the internet). Netherlands has the biggest number of web surfers, with a rate of Internet usage by 87,8 percent. The following are ranked Sweden, formerly, occupying the first place with 77,3 percent and Portugal with 73,1 percent.

Total number of internet users has reached 1.2 billion people, of the 6.6 billion planet inhabitants. Most Internet users - 461, 7 million people - coming from Asia, where the penetration rate is only 12.4 percent of the total population which is approaching 3.8 billion people (Daniel, B., 2008). According to the annual report on the progress of ICT in 2007 the Internet has attracted nearly 40 million additional new users in the EU, to a total of 250 million regular internet users. Despite the progress made, 40 per cent of the EU population has never used the Internet. More than half of Europeans use the Internet regularly, 80 percent of them have broadband connections, while $60 \%$ of public services in the European Union are integrally available on the internet. Two-thirds of schools and half of physicians use high speed Internet thanks to a powerful extension of broadband Internet in Europe.

On the other hand in many EU countries people don't use the Internet regularly. One of the objectives of the European Commission is that the Europeans to make the most profit from eHealth, a concept that implies primary physicians to be connected to the internet, to use the Internet during the consultations, to be created a network linking various health institutions and patients to receive test results electronically. According to the report, the percentage of family doctors who are connected to the internet, Romania is in last place, far ahead of other countries in the bottom classification. Thus, among family doctors from Denmark, the broadband Internet has a penetration of 91 percent, compared to Romania with only 5 percent. The penultimate on top is Slovakia with 15 percent, while for Bulgaria the percentage is about 22 percent. The report's conclusion was that the most developed countries in terms of infrastructure and Internet use are Denmark, Finland, Iceland, Netherlands, Norway, Sweden, Austria, Belgium and Germany, and the most underdeveloped ones are Bulgaria, Cyprus, Greece, Poland and Romania.

\section{The power of new Internet interfaces}

YouTube is a website that effectively revolutionized the Internet since January 2005(Bica, M., 2006). The three founders, Chad Hurley (29 years old), Steve Chen (28 years old) and Jawed Karim, who had just finished their studies, had been at a party with friends in San Francisco, where they filmed a few funny clips. When they got home, they wanted to send each other movies through e-mail, which was not possible because they were too large. Neither posting of video sequences on the Internet was a solution, so the three thought that a particular thing needed to be done in this regard, therefore they created a simple website where people from around the world could post in just a few minutes - any video clip. When not at work, the three used to meet and work in a garage. The founders have made it so that those who were 
registered on the site could comment all posted videos and could even add on their own sites the clips they found interesting on YouTube.

Since it was launched, tens of thousands of videos are put daily on this site, which means an absolute record. The basic idea is that anyone can post anything on YouTube (or just about anything, except pornographic videos) and millions of people around the world can watch videos without the need for credit card, recordings or additional software programs. This has led to the explosion of the site popularity. On YouTube you can see all kinds of clips: From Mihail Barasnikov in the Ballet Giselle in 1977, the kids that make all sorts of funny gestures in front webcam, or memorable moments from various programs or news. Singing, dancing, reciting, playing all sorts of funny moments like "candid camera", as well as things, institutions or successful individuals are taunted, in a few words, any citizen of the planet, which has access to a computer connected to the Internet can make his own movie, then can make it public all over the world.

In the summer of 2006 after various investments, YouTube has become one of the sites with the fastest development on www. According to a survey conducted in July 2006, a hundred million videos were viewed on a daily basis on this site, and only in 24 hours are posted on average 65,000 new videos-. Every month, the site has around 20 million visitors. These statistics being since 6 years, it is obvious that they are no longer actualized...

In August 2006, YouTube announced that by early 2008, will be able to offer any music video ever created. Aware of the potential, Warner Music Group and EMI have confirmed that they are part of the companies that have contributed to this plan implementation. A month later, Warner Music and YouTube have signed an agreement by which YouTube has permission to host any music video ever created by Warner if an advertisement will be broadcasted from the beginning.

In October 2006, Google announced that it had bought YouTube for the record sum of $\$ 1.6$ billion in equities, so that the three founders have become multi-millionaires «overnight». In addition to great success YouTube was confronted with legal copyright issues, when leading companies have announced they will sue them if they continue to publish videos that are protected from the copyright point of view. This has changed a bit the site policy, which removed the videos that were protected by copyright law.

Certainly, 2006 has been a year of the Internet, a fact recognized by Time magazine, which named as personality of the year- The Internet user - i.e. every person who is contributing to the development of networks and companies. Representatives of Time magazine said that the Internet has changed the balance of the media through blogs, web video networks as well as socialization. Time gave as examples names of sites like YouTube, Facebook, MySpace and Wikipedia that allow users to interact by uploading and publishing their own comments, videos, photos and links. «lt is about taking power from the hands of a small group of people and helping others free of charge. This will not only change the world, but also the way the world will be changed» declared Lev Grossman, Time magazine.

Increasingly more companies flock to social networks, agencies specialized in web 2.0 appear like mushrooms and digital existence question is no longer how the webpage looks like, but what web strategy to follow ${ }^{1}$. Even companies with more progressive visions struggle with new digital communication channels. In fact we are all private individuals as well as institutions affected by a change that media has not seen since the invention of the printing press. Who would have thought after the dot.com bubble earlier this decade that the Internet will flourish at such a fast pace? The User has recaptured the network, inhabiting it and conquering new possibilities. And the mass creates relevancy: 100 million clips are watched daily on YouTube, 45 new clips are added every minute. Wikipedia includes only in high circulation languages over 9 million articles. Taking into account only the number of photographs on Facebok- around 4 billion each person and a half is present on the flicker. If social networks were states, they would be since a long time present at the G8 table: 350 million users on Facebook, which total five billion minutes daily use. Neither the populations of China nor India are so great.

Internet networks become main business and relationship environment. According to a study of the ARD/ZDF, 96 percent of Germans aged between 14 and 29 years old use the Internet regularly, and those aged between 30 and 49 years who use it are at the level of 84,2 per cent. From all social levels new users are added: even from those ageing over 50, called "silver surfer" in the marking slang, the percentage rises to 41 percent. So, we're talking about 43.5 million only in Germany. Their tracks on the net are visible; the used results can be analyzed as a basis for potential communication strategies.

Thanks to Web 2.0, these people are no longer just consumers. The digital revolution has given them access to the tools and platforms to present their opinions and messages to potentially global audience. Every mobile phone, offers the 
possibility of filming your own ideas. Platforms like YouTube allow global distribution. Also the "means of production" were never available to the individual. Even though most of these productions are seen by media professional producers as "loser generated content" media digitization leads to their democratization. Everyone is a potential customer, but at the same time, a Community member, a producer and a multiplier. At an average of 130 friends per user on Facebook, it means a tremendous market power. While working environments are well known. It is not "rocket science". The Internet is on the basis of any advertisements. Tens of thousands of editors and experts in the PR field navigate the internet daily looking to improve their careers.

Business communication of any nature would it be, can no longer be done at present only through traditional media means. The communication is done via social media increasingly more often, depending on the groups to whom they are addressed,. The Frenchman Régis Debray has founded the basis of a new discipline - mediology - extremely actual, a key and a tool through which we can analyze society events at a global level. It is obvious more than ever, that we live in an age of media, in which traditional media - print and audio-visual media, coexist and are increasingly competed by nontraditional media, named "social media" means as well. Among which can be mentioned: blogs, social networks like Twitter, Facebook, MySpace or multi-media tools like Youtube, Flickr or sharing of opinions and information dissemination to Wikipedia, GoogleReader, e-opinions.

Blogs or Twitter network are listed among the favorite communication tools of the consultancy companies working in the field of European public affairs. Therefore, on the occasion of elections to the European Parliament in June 2009, such company has created a particular blog on which is posted all the public information, especially the unofficial one, that company has learned through its own means. This is called, "intelligence tracking in the jargon of specialists in European public affairs in Brussels. In the aftermath of European elections, until consecutive meetings of the European Parliament and parliamentary committees, the company blog in question was highly accessible by all those interested to know the information in the premiere, behind the scenes, related to European parliamentarians, parliamentary commissions or membership negotiations between the political groups. Moreover, some of the information was found on Twitter network as well.

Prestigious publications, such as "Financial Times", "The Economist" or "EuObserver" have special blogs dedicated to European Affairs, in which many interesting opinions and ideas are found. They sometimes represent an addition of articles from respective publications or, not infrequently, from a more direct angle approach to European topics. The newspaper "Liberation" blog of correspondent Jean Quatremer in Brussels (among other things, was the one who essentially contributed, through its disclosures, to Commission resignation, led by Jacques Santer in 1999) is a "destination" for any actor of the European public space who wants to learn new information, especially about the European Commission and the European Parliament.

\section{New directions of virtual communications}

Finland is officially the first country in the world where the broadband Internet is a legal right for citizens, the same as health and education. As of July 1, 2010, any Finnish citizen has the right to have access to a broadband connection of at least $1 \mathrm{Mbps}$ (megabit per second). Finnish authorities have promised that they will connect the entire population at a speed of $100 \mathrm{Mbps}$ until 2015. All telecommunication companies will be obligated to provide all Finnish residents with broadband lines that offer a data transfer rate of at least one megabyte per second. Finland is one of the countries with the highest Internet penetration in the world. About 96 percent of Finns have access to the internet while only 4,000 homes across the country did not have access to the internet in mid-2010.

The European Union wishes to promote neutrality in the virtual environment. In this respect, the European Commission published on April 19, 2011 proposals for promoting a virtual, neutral and competitive space, offering as an example the major industry actors for their prudence, while consumer groups and activists deplored the current state of the Internet. Although much time has passed since the U.S. has implemented a series of legislative measures to ensure an open virtual environment, the European Union is trying to keep up and acting as such.

The Internet has brought upon itself in the last 15 years economic growth superior to that made in the 50 years of the industrial revolution in the 19th century, shows a study by the McKinsey Global Institute among the 4,800 SMEs from 13 important countries of the planet (Germany, France, Sweden, United Kingdom, USA, Canada, Italy, Japan, India, China, Brazil, Russia and South Korea). These countries together hold 70 percent of the world GDP, while selected companies have invested in internet technology (Barza, V., 2011). If the Internet was considered a sector of the economy itself, it would have a higher proportion of GDP than sectors such as agriculture or education, which emphasizes that progress, is a factor of prime importance. 
McKinsey Global Institute points out in its study the facts that seem aberrant, paradoxical until they will be confirmed by other sources, and that the Internet has contributed by $21 \%$ to GDP growth in the industrialized countries during the last 5 years, while in Germany, the contribution was 24 percent or 33\% in Sweden. Although the Internet has brought, thanks to the automation of some processes, the abolition of some jobs, overall the number of jobs created is 2.4 greater than the number of jobs terminated because of internet arrival.

Research companies estimate that the market for "cloud computing" will double every two years and will reach 7085 billion dollars in 2015.

Vint Cerf, called "father of the Internet", considered one of the leading researchers in the field of computers, said that businesses and consumers need to act now in order to move on to the next generation of web addresses ${ }^{2}$. If preparations do not start now, some computers might not be able to connect online and the Internet connection will be affected- he said. Network engineers estimate that we may remain without addresses that can be allocated in about two years. Therefore, Internet supplier services should be prepared because every computer has a unique IP address, while not allocated addresses are limited. Cerf explained that it is as if the phone numbers would be terminated. No new numbers, no one can subscribe. When Cerf, along with other researchers, founded the Internet in 1977, he installed "Internet Protocol version 4 (IPv4), which provided 4.2 billion addresses. Currently, less than 14\% of these addresses remain free. It is estimated that IPv4 addresses, each of which is an array of 32-bit, will terminate in 2014. A new system, IPv6, is ready to be implemented for more than a decade. In IPv6, each address has 128 bits and the system provides 340 trillion trillion trillion addresses $(340,000,000,000,000,000,000,000,000,000)$. It is estimated that these addresses will be sufficient for the following decades.

\section{Conclusions}

Everyone knows that the Internet is of paramount importance, however a few people understand how much economic growth helps, how economic growth brings jobs and technological advance. If it was considered an economic sector of its own, the Internet would hold values from 3 to 33 percent of GDP in countries that would have the courage to measure its effects in this important economic indicator, rather than dedicated sectors, such as agriculture or education. The U.S. is the most important country for the global Internet, generating $30 \%$ of revenue, while in China and India the Internet effect in economy has enormously grown during recent years.

Actually, the communication of any kind would be, can no longer be effectuated only through traditional media. Increasingly more often, depending on groups addressed the communication is done via social media, hypermedia. At the same time, more and more people communicate information regarding their activity on personal websites and/or blogs, and a large number of people- which is growing very fast- are already present in networks like Facebook or Twitter.

Currently, four of the seven billion inhabitants of the planet use internet annually, its influences on planet economy are comparable to "printing revolution "- generated by Gutenberg's invention or other "revolutions", produced by the "steam power" or electricity.

\section{References}

Barza, V., Internetul a ajutat creşterea economică mai mult decât revoluţia industrială în secolul 19 - studiu, pe site-ul http://www.hotnews.ro/articole_autor/Vlad\%20Barza, vizitat pe 25 mai 2011, hr., 6:31

Bica, M., "The invention of year 2006", December 19, 2006

Bica, M., Invenţia anului 2006, în Ziua, 19 decembrie 2006

Daniel, B., "More Internet users" in Compact, 17 January 2008, p.7

Daniel, B., Suntem mai mulţi internauţi, în Compact, 17 ianuarie 2008, p. 7

Stork, V., "The Internet has helped economic growth more than the industrial revolution in the 19th century - study site, visited on May 25,2011 , at 6:31, and on-site

Ulieru, M., Rezidenţi în nuca digitală, în Ziarul de duminică, 25 ianuarie 2008, p. 5

Vasiu I., Cybecrime, Bucharest, Nemira, 1998, p.121-122

Vasiu I., 1998 p. 173 